\title{
Balkanologie
}

Balkanologie Revue d'études pluridisciplinaires

Vol. II, nº 1 | 1998

Volume II Numéro 1

\section{Legitimation crisis of state socialism}

The Balkans vis-à-vis the Visegrád countries

\section{Fatos Tarifa}

\section{(2) OpenEdition}

\section{Journals}

Electronic version

URL: http://journals.openedition.org/balkanologie/235

DOI: 10.4000/balkanologie.235

ISSN: 1965-0582

\section{Publisher}

Association française d'études sur les Balkans (Afebalk)

\section{Printed version}

Date of publication: 1 July 1998

ISSN: 1279-7952

\section{Electronic reference}

Fatos Tarifa, « Legitimation crisis of state socialism », Balkanologie [Online], Vol. II, n 1 | 1998, Online since 02 June 2008, connection on 17 December 2020. URL : http://journals.openedition.org/ balkanologie/235; DOI : https://doi.org/10.4000/balkanologie.235

This text was automatically generated on 17 December 2020.

(c) Tous droits réservés 


\title{
Legitimation crisis of state socialism
}

\author{
The Balkans vis-à-vis the Visegrád countries
}

\author{
Fatos Tarifa
}

1 Although it was arguably well justified and legitimized for millions of Soviets and East Europeans who passionately believed in Communist ideals, the Communist system forfeited much of its legitimacy long before its final collapse. In the early 1970s, Kolakowski described the Communist regimes in Central and Eastern Europe as systems dying «a slow political death $»^{1}$. After all, the legitimacy of Communist systems that was once a product of a revolutionary past, the glorious victory over the fascists and the Nazis at the end of World War II, could not have been justifiable and unquestionable on ideological grounds alone for too long. It was, indeed, seriously questioned and undermined when state socialism and the Communist parties throughout the region proved unable to realize the societas perfecta they once promised their citizens and consolidated their powers due to the ruthlessness with which they pursued this aim and the thoroughness with which most of these regimes were made into virtual copies of the Soviet system. Alfred Meyer called this process of draining of content of Communist ideology the "withering away of utopia $»^{2}$. This gap doubtless was for a long time a major cause of political strain in all Communist-ruled countries. And, even if only vaguely, such strain was felt not only by intellectuals and the working people, but also by many officials, thus contributing to a continuous growth of legitimation crisis. Although gradual and not uniform, this unavoidably drained the political legitimacy of state socialism.

\section{Legitimation crisis}

2 Genuine legitimation crises in the sense of various kinds of unrest among the population and within the Communist parties and, more importantly, large-scale upheavals in which blood was spilled, repeatedly broke out in several East European countries : in the GDR in 1953, in Poland and Hungary in 1956, in Czechoslovakia in 1968, and again in Poland, the most maverick and rebellious of all Soviet-bloc countries, on a number of occasions : 1970, 1976, and most notably in 1980-1981. All these major 
events represented authentic working-class movements, with general strikes, factory occupations, elections of worker's committees, etc. In spite of their individual characteristics they expressed but one message : large segments of the working class and the intellectuals had lost faith in state socialism and regarded their Communist leaderships as being corrupt, hence illegitimate to rule.

Piven and Cloward ${ }^{3}$ and Oberschall ${ }^{4}$ suggest that mobilization and collective action against any authority occur particularly when the legitimacy of its policies and practices is called into question. However, one should not underestimate the changes in the political opportunity structure when Stalin's iron fist was no longer there to remind East Europeans that any move from the status quo would had been harshly sanctioned. Several authors ${ }^{5}$ have argued that the outbreak in Poland and the revolution in Hungary in 1956 would have been unthinkable without the prior removal of the Stalinist lid from the boiling satellite kettle. Similarly, what happened in Central and Eastern Europe in 1989 would have been difficult to imagine, if not impossible, had Gorbachev's "Sinatra Doctrine" not removed fears that the 1956 and the 1968 events might be repeated. Although the Soviet hands-off policy had not, as yet, been tested for its limits, observers agree that Gorbachev's signals of welcome reforms in Eastern Europe and non-intervention in internal affairs were a crucial factor leading to the 1989 democracy movements 6 .

\section{The Balkans vis-à-vis the Visegrád Countries}

4 Characteristically, crises of state socialism broke out mainly, and most dramatically, in "Habsburg" Central Europe, to use Rupnik's language. Several factors may explain this. First, compared to the Balkan countries, Yugoslavia and Albania in particular, the Communist parties and their leaders in Central Europe had had sparse popular backing and a much lower degree of legitimacy from the outset. While regimes in these countries could be sustained by Soviet economic and military aid, this was at the expense of their legitimacy and their countries' national autonomy.

5 Second, communist indoctrination in the Central European countries had been more superficial, hence, relatively easier to reverse. For most people in these countries Marxism-Leninism remained an alien ideology unintegrated into consciousness and practice except in a wholly superficial manner.

6 Third, although they were under Communist authoritarian rule, the Visegrád countries did not experience the harsh repression of the hard-line Communist states of the Balkans, Albania and Romania in particular ${ }^{7}$.

7 Fourth, none of the Central European Communist regimes (arguably except for Poland's Gomulka rule) ever evolved charismatic authority through the use of their leaders' "cult of personality", as was the case with Tito in Yugoslavia and Hoxha in Albania. With their flair and national appeal, the latter were regarded as genuinely popular leaders and national heroes in their respective countries. They were viewed by the masses as the revolution incarnates, the heroes who miraculously had led their peoples out of the atrocities of fascist and Nazi occupations and the backwardness of their authoritarian past.

8 Fifth, all the Balkan countries were indisputably more agrarian and impoverished than their Central European counterparts. This made their economic and social achievements during the initial phase of socialist construction look even more 
remarkable and granted ample legitimacy to their Communist leaderships. Like other Communist countries of Central Europe, the Balkans experienced rapid industrialization and urbanization, and a substantial economic growth in the 1950s and the 1960s, as well as remarkable improvement in their standards of living through the 1960s and the 1970s.

Meyer's insightful idea that for assessing the legitimacy of power in Eastern Europe it is important to single out the group(s) whose attitudes are most essential to maintain the system $^{8}$ is very relevant to this analysis. In virtually all the Balkan countries that group was the peasantry, which was not only the largest numerically, but also the most important social group in determining the success of the post World War II order. Neglected and exploited for many centuries, the peasants, and arguably the newly created industrial working class, gained more in the earlier phase of the socialist construction than any other group. As in most of Eastern Europe, the working class in these countries resulted basically from the large migration of the rural population to rapidly industrialized urban areas. Because large segments of industrial workers had their roots embedded in the countryside, they had no political consciousness distinct from that of the peasantry. It was among the peasantry that the Communist parties in the Balkans had more support than among any other social group. The more rural and underdeveloped a country, the more confident and stronger the Communist party and its power". The lack of a substantial middle class or petit bourgeoisie in the Balkans contributed to an easier and smoother acquisition and maintenance of power by the Communists who faced virtually no organized opposition, as they did in the more developed Socialist Hungary, Poland, and Czechoslovakia.

In Yugoslavia, Tito's arguably well legitimized rule was in a large part determined by the strategic choices made after his break with Stalin and by his ability to hold the Yugoslav Federation together with little cost. With Tito and Titoism, the conception of Moscow as an invincible Communist monopoly was destroyed and an alternative model of socialism provided. In her heyday under Tito, Yugoslavia became, indeed, history's first example of an affluent, or at least semi-affluent, Marxist society, in which the state pursued policies to promote the material and immaterial satisfactions of the individual rather than to achieve a purely collective well-being.

11 In Albania, the smallest and the poorest Communist country in Eastern Europe, the Communists attained a stronger support among the predominantly agrarian population than in any other country right from the start. Szelényi and Szelényi rightly observe that the more impoverished the East European countries the more dramatic the improvements ${ }^{10}$. There is no doubt that the economic life in most of these countries after World War II, particularly in the Balkans, was a good deal more affluent than in the period between the two wars. There is also no denying the greater economic justice, security, life expectancy, and social integration that most East Europeans enjoyed under various periods of Communist rule. In Albania, in particular, the strikingly rapid economic growth experienced in the 1950s and 1960s, which contrasted with the extremely low initial level seemed enormous, as well as considerable achievements made in social equality, housing, employment, literacy, health care, education, and culture, impressed the population. All these were credited to Hoxha's leadership, further bolstering his popularity and the legitimacy of his rule. One need not be reminded, however, that all these strides were amplified and filtered in a mystified form through the state-controlled propaganda machine : newspapers, radio, 
television, public gatherings, speeches. Information was disseminated with repetition of such absolutes as : "the most democratic system in history ", " the happiest nation in the world ", « one hundred per cent electoral participation », « one hundred per cent of votes in favor of the regime ".

In Bulgaria, the second least industrialized East European country, initial support for the Communists and consent on their title to rule was largely achieved due to Georgi Dimitrov's immense popularity and the good record of the Communist resistance against the Axis, a factor which was absent in post-War Rumania. This, however, can not be said for Todor Zhivkov, who led one of the least imaginative Communist rules in Eastern Europe.

To summarize, three important factors may explain why Communist rule in South Eastern Europe remained unchallenged, unlike that of Central European countries, by strong rational-critical opposition movements or mass upheavals: a) their more predominant agrarian and backward character; b) stronger initial support for the Communist parties; and c) harsher repression of political opponents. Not only was there nothing among the Balkan countries to compare with the Hungarians' 1956 revolution or the Polish recurrent rebellions, but there was not even any serious resistance that could threaten the power system. Nor were there any forms of organized opposition or working-class activism in the hard-line Communist states of the Balkans. Even if they were sporadic attempts to oppose the established political course, they were nipped in the bud. Seemingly, the population in these countries had less incentive to press for change until events in the Soviet Union set into motion a cumulative process that resulted in the dramatic collapse of the entire system in all countries of Central and Eastern Europe.

Although all the Balkan Communist states had legitimation problems and legitimation deficits, they did not experience legitimation crises like the Communist rules in Central Europe. "Legitimation needs", Habermas observes, "do not have to culminate in a crisis $»^{11}$. Yet, whenever Communist leaders and top officials were purged and succession problems emerged, whenever domestic economies failed to produce more than rationed food for the growing populations, whenever the younger generation questioned the old realities and practices and social integration was endangered, there was a condition, albeit not always clearly manifested, of legitimation crisis. Kateb argues that

a legitimation crisis need not be a definite thing... It could exist without full explicitness, without people knowing how really disaffected or hostile they were. In the past, great political and social convulsions have sometimes come as a surprise to everyone, including the disaffected and the hostile. Some incident or opportunity, or some quick, sharp change in condition was needed to crystallize and then to energize the sentiments of crisis. ${ }^{12}$

\section{The « New Course »}

The move from Stalinist orthodoxy, the new policy of "peaceful coexistence" and a range of fundamental ideological revisions and revisionist policies that were carried out by the $20^{\text {th }}$ Congress of the Communist Party of the USSR (1956) and which were more or less pursued in all Central and East European countries in the late 1950s and 1960s, except for Albania and, of course, Yugoslavia, which has always been a special case, may be seen as attempts to impede the erosion of regime legitimacy in these 
countries. These changes sought to give the system a more "human face", making limited adjustments to the system, and producing a certain amount of "liberalism" and some breathing room to carry out economic reforms without risking massive civil disobedience. Osiatynski labels the period from 1956 until the mid-sixties, during which the "New Course" was implemented, as a period of "nationalist communism ${ }^{13}$. As argued by Brown, the aim behind this "new course" adopted by Khrushchev and the new ruling elites in Central and Eastern Europe was to make the Communist system more viable, more legitimate, and more attractive to its citizens ${ }^{14}$.

The history of East European socialism provides a number of examples of Communist parties and leaders' attempts to restore or renew the basis of their internal legitimacy and even generate legitimacy in the international arena for their rules with nationalistic rhetoric and by carefully crafted national programs which were directed against Soviet supremacy ${ }^{15}$. Tito, Hoxha, and Ceauşescu seemed to use such nationalistic rhetoric more successfully then others. However, efforts to introduce alternative models of socialism, such as Gomulka's "Polish Road to Socialism" and Kádár's "Hungarian Socialism" were also of some success in infusing internal legitimacy for their regimes. As Chirot observes, « in Poland and Hungary, foreign loans started to be used simply to purchase consumer goods to make people happier, to shore up the crumbling legitimacy of regimes that had lost what youthful vigor they had once possessed and were now viewed simply as tools of a backward occupying power. This worked until the bills came due, and prices had to be raised $»^{16}$.

During this period, leaderships changed throughout Central and Eastern Europe. Whenever Soviet rulers lost confidence in East European party leaders, the Kremlin engineered such changes in an effort to restore orthodox control. Local leaders who resisted Soviet demands or attempted to pursue an independent route to building a socialist society were replaced with those more pliant to Moscow. It was quite logical that changes among leadership groups in Central and Eastern Europe would indeed follow major shifts among political elites in the Soviet Union.

\section{Tito, Hoxha, Kádár}

18 Tito and Hoxha, the only Communist leaders in Eastern Europe who had deserted the Soviet-ruled Communist bloc, were the only ones who continued to rule firmly and even consolidate their powers. Neither was ever seriously challenged by political opponents, and their legitimating charismatic myth remained virtually intact throughout their lives. However, after the break with the Soviet Union, both domestic and international circumstances for Albania and Yugoslavia differed in every respect. Tito's Yugoslavia opened its doors to Western diplomatic and commercial ties and to foreign capital investment, becoming the only Communist country accorded mostfavored-nation status in trade with the United States, and raising the living standards higher than virtually all other socialist countries. Not only did Yugoslavia receive vast infusions of aid from the West, it also enjoyed wide recognition for its "original", albeit failing, self-management model of socialism and its leading role in the world-wide movement of "non-aligned states".

Albania went the opposite way, closing its doors even more to the outside world and severely restricting not only the movement of people but also the flow of information into and within the country. After Hoxha's break with China in 1976, a new 
Constitution proclaimed "self-reliance" to be the main principle of socialist construction in Albania, prohibiting any foreign credit, aid, or investment. Such a go-italone policy inevitably led to severe economic slowdown and pervasive shortages of food, clothing, and services. Maintaining Hoxha's legitimate authority during such a period of widespread personal hardship was not easy. Indeed, it is hard to gauge Hoxha's success in the 1970s and first half of the 1980s in engendering support for Albanian Communist leadership and its policies. Much of the earlier euphoria had dissipated but large segments of the population continued to follow the Party elite giving at least tacit support to its policies.

The legitimacy of the party-state rule and its leaders in Albania during the 1970s and the 1980s might be viewed as based, in part, on negative rather than positive appeals. The time of "spectacular achievements" was over. The country went through a long period of stagnation, consecutive economic failures, and severe political restrictions for its citizens.

21 A similar situation existed in other countries, particularly in Bulgaria and Rumania. This led to deep and widespread disaffection with economic and political realities, seriously affecting the leadership's legitimacy. Citizens in all these countries began to question : Why are there shortages? Why are there hardships? Why is political control so strict? What has brought these about?

Albanian leadership, unlike the Soviet-controlled regimes of the Socialist block, justified themselves and the economic hardships with the "emergency" argument : we are the sole truly socialist country and the very citadel of Marxism-Leninism. For that reason, we are entirely surrounded by a hostile world, by powerful enemies who regard us as "a thorn in their flesh" and try to isolate us from the outside world and make us give up our socialist ways ${ }^{17}$. This rationale, as presented to the Albanian people, was aimed not only at camouflaging the reverse of Communist ideology from a legitimizer of revolution to one of unconditional obedience, it was also an attempt to divert attention from pressing domestic problems, misdeeds, and incompetence of the leadership by blaming others for the failures of the system and the broken promises of the earlier days of Communist takeover. Yet, such a policy of concealment and overindoctrination came at the expense of the power's stability and legitimacy. It could turn, as in fact it did, into deep and widespread disappointment with and alienation from the system. As Betrand Russell pointed out long ago, a policy of concealment often produces effects exactly opposite of those intended. « Some, at least, of the unpleasant facts which had been kept dark are likely to become patent to all, and the more men have been made to live in a fool's paradise, the more they will be horrified and discouraged by the reality. Revolution or sudden collapse is much more probable in such circumstances than when free discussion has prepared the public mind for painful events $»^{18}$.

In all other East European countries, promises neglected by the old leaders were renewed and amplified by the new governing teams in the 1960s and the 1970s in hope of restoring their regimes' political legitimacy. Yet, only a reformed Hungarian state socialism, known as "goulash Communism" under János Kádár, arguably one of the most popular Communist leaders in the 1960s and 1970s, was able to refurbish a certain degree of legitimacy. Kádár's strategy of « he who is not against us is with us " proved successful in allowing his regime to survive the trauma of 1956 and to restore its 
legitimate authority by ceasing repression and allowing intelligentsia some rights to dissent ${ }^{19}$.

However, this does not suggest that Communist rule was established and remained for such a long time only on the basis of its legitimacy. As Collins points out, "political domination does not depend solely on legitimacy. Widespread emotions of legitimacy make it easier to rule; but the existence of armaments in the hands of a few can enforce domination a good deal of the time, especially in the absence of some strongly organized movement of revolt, which itself would require a strong countralegitimacy $»^{20}$.

Once established, the Communist regimes in Central and Eastern Europe, like other forms of rule, could survive and, indeed, maintained their power much of the time by routine and persuasion, though with a relatively low degree of legitimacy. Even after great loss of legitimacy has occurred, a state can remain quite stable, and certainly invulnerable to internal mass-based revolts, especially if its coercive organizations remain coherent and effective ${ }^{21}$.

\section{The Death of a System}

Describing legitimate authority as the capacity of a government to maintain confidence in the power system, Hannah Arendt wrote that «no revolution ever succeeded, few revolutions ever started, so long as the authority of the body politic was indeed intact $\aleph^{22}$. Her view is once again fully confirmed in the East European revolutions of 1989-1990. The gradual erosion of the legitimacy of East European socialism, which eventually brought about the collapse of the entire system, was an inescapable result of several political, ideological, economic, and cultural factors.

In light of the above discussion, it is reasonable to consider the main causes that deprived state socialism of legitimacy. The main arguments in the recent scholarly debate focus on two major factors, which Kolakowski metaphorically terms the "body" (the economy) and the "mind" (the ideology) ${ }^{23}$. These two factors, indeed, form the core of all attempted explanations.

\section{The Body}

A common view in current scholarship holds that the decisive factor draining the legitimacy of the Socialist system was the inefficiency of Sovietism as an economic order, its repeated failures to fulfill people's increasing expectations and even their basic economic demands. Such a view derives from the belief in the primacy of the economy vis-à-vis politics, which, as Luhmann observes, is manifested through the extent to which "judgement of political success is made to depend on economic success $»^{24}$. According to this view, Communist-party states based their claim to legitimate authority on their ability to promote economic growth, to provide a steady and improving flow of goods and services, even promising their citizenry to catch up with and overtake the standard of living of advanced capitalist societies. Despite some initial economic and social achievements, it became clear that the socialist state was unable to deliver on economic promises, hence its legitimacy was undermined. 
Whatever reasons can be provided to explain the legitimacy loss of state socialism, there is one point on which there is a general consensus among scholars of comparative politics : regime legitimacy, and socialism is no exception to this rule, is significantly correlated with the efficiency of the system, efficiency understood as actual performance of the government, the extent to which it satisfies the basic functions as the population at large and key power groups see them ${ }^{25}$. Viewed from this point, the Soviet-type system, although extremely effective, effectiveness defined here as the capacity to attain objectives, was, paradoxically, extraordinarily wasteful and inefficient. McSweeney and Tempest emphasize this point in the context of a series of comparative disadvantages with the West, which demonstrate the implausibility of socialism to prove its claimed superiority over capitalism ${ }^{26}$. These authors point particularly to the consumer boom experienced by the major capitalist economies in the mid-1980s, a time during which all East European countries were afflicted by unprecedented low, and falling, growth rates. It was difficult, these authors assert, not to link the efficiency of the market economies to their social and political systems.

A number of authors develop a similar argument : it was the failure of "real existing socialism" to promote productivity ${ }^{27}$ and the perception of a rapidly growing technological and economic gap between state socialist economies and the advanced market economies ${ }^{28}$ that played the most decisive role in the decline of the legitimacy of state socialism and pushed the Communist elites to initiate economic reforms. As people began to measure the economic performance of their socialist system no longer against the backwardness of the past but against the advanced capitalist economies, they realized the deficiency of state socialism as an economic and political order and pressed for change. The sharp contrast between East and West thus helped to delegitimize the Communist ideology, the socialist practices, and the ruling elites ${ }^{29}$. As argued by Nee and Lian, " generally speaking, when a communist party opens its door to the outside world, people there immediately recognize the large gap of living standards between western countries and the socialist state. Future expectation might speed up the decline of commitment to the party $»^{30}$.

\section{The Mind}

Another line of argument refers to the ideological failures of state socialism as the determining factor which deprived the system of all moral validity and drained away the reservoir of popular support. This argument is elaborated with particular clarity by Kolakowski, who argues that the basis of legitimacy of the Communist rule was primarily derived from the ideological principles that justified the organization of the Soviet-type society and established its place in history ${ }^{31}$. Hence, Kolakowski points out, totalitarian Communist states in Eastern Europe could survive their highly inefficient and wasteful economies as long as the ideological devices served to justify the system ${ }^{32}$.

Following this rationale, one might then argue: when peoples' beliefs in an ideology which justifies a given order of production and distribution erodes, the system's legitimacy declines and vanishes. Consequently, the system loses its raison d'être. In the case of the Soviet-type systems, with the erosion of Communist ideology, the main pillar upon which the claim to legitimate authority had been historically based, the roots of the establishment were dried up and the entire building fell apart. Fukuyama makes a similar point asserting that «the critical weakness that eventually toppled 
these strong states was in the last analysis a failure of legitimacy - that is, a crisis on the level of ideas $»^{33}$. The underlying idea of such an argument is that if beliefs have power, as history, the distant and the recent, clearly illustrates, then a crises of beliefs will most certainly affect the strength of power systems and undermine their legitimacy. Beliefs in the legitimacy of a given order and the subjects' willingness to submit to a particular policy or to a government may be altered because of new beliefs, or new insights into old ones, and because of changes in perceptions of the established system.

\section{The Body Politics}

Chirot, Szelényi and Szelényi, de Gaay Fortman and other authors also reject an exclusively economic explanation for the erosion of the legitimacy of state socialism and the demise of the system as too simple ${ }^{34}$. These authors emphasize the political aspect of state socialism, its inability to develop as a democratic system rather than its ideological failures or economic weakness. "It is quite imaginable that the major weakness of the socialist project was not economic at all : it was political. The major problem with socialism was not that it did not work as an economic system, but that it was unable to establish itself as a democratic system and in the long run this undermined its legitimacy ${ }^{35}$.

It is common knowledge that the economic growth in virtually all the former Communist states began slowing, even when based on their own estimations, since the latter part of the 1960s. All socialist states came to a turning point in their overall economic conditions somewhere in the 1970s. None of them was able to overcome the shortage of production, which became particularly significant in the early 1980s. In the period between 1965 and 1985, the rate of increase of GNP in the Soviet Union, for instance, fell from $8 \%$ to $3,2 \%{ }^{36}$. In short, the socialist system resulted in enormous wastage of human and material resources and inefficiency ${ }^{37}$. Such a system, based on central planning, became increasingly incapable of supplying expanding demands. Menshikov has remarkably defined the socialist system as one which tends to «recreate or reproduce deficit conditions». By killing incentives, state socialism continuously reproduces and reestablishes "conditions of inadequate supply and abundant demand $»^{38}$.

Yet, the economic decline of socialist states, which further escalated by the late 1970s and during the 1980s, only chipped away at the already fragile political legitimacy of their government. In other words, economic problems assumed critical importance only after an initial erosion or delegitimization of existing authority. As Kolakowski argues, it was not the level of absolute or even relative material satisfaction to which the collapse of the communist regime may be attributed, but the inexorable erosion of belief in Communism and the changes in peoples' mentality. "All the unfulfilled promises and dashed expectations of a better life fuel the revolutionary energy. But the real source of this energy is to be looked for in changes in mentality ». This author concludes: " perhaps, the strongest case against Marx's immortal phrase that "social being determines consciousness" is provided by the history of the states that have assimilated this very phrase as part of their ideology ${ }^{39}$. 


\section{A Catch 22 ?}

For either of the above hypotheses there is a good deal of supporting evidence; however, neither is subject to convincing verification or falsification. For it is impossible to state firmly whether it was the failure of Communist ideology that led to irrational and wasteful socialist economies thereby delegitimating state socialism, or the consecutive economic failures in all socialist countries which delegitimized the Communist ideology and the political system in which this ideology was embodied. This does not, of course, mean that the two arguments simply lie parallel to one another; they are dialectically related to one another in such a way that « economic collapse may have been as much the result of the lack of political legitimacy as its cause ${ }^{40}$. Therefore, neither a one-sided economic interpretation nor a one-sided ideological explanation can provide a satisfactory answer to the question of the demise of socialism. Understanding the causes of the withdrawal of legitimacy of state socialism requires a combination of the two perspectives.

Or, one might well conclude with Ismail Kadare that it may still be too soon to speak about the causes of the demise of Communism in Eastern Europe and in the Soviet Union. For we are not as yet far enough away to grasp and render a judgement on the historical landscape in which Communism arose, expanded, developed, and collapsed. " The record of events is too fresh to be gauged with any precision. We have no way of knowing its victories and defeats, since...the eye is bound to see amiss - so much so that where Communism has triumphed it may seem to have been vanquished and, inversely, where it has appeared invulnerable it may in fact have been beaten $»^{41}$.

\section{NOTES}

1. Kolakowski (Leszek), « Hopes and Hopelessness », Survey, 17 (3), 1971, p. 80.

2. Meyer (Alfred, G), "The Functions of Ideology in the Soviet Political System », Soviet Studies, 17 (3), 1966.

3. Piven (Frances, F.), Cloward (Richard, A.), Poor People's Movements: Why They Succeed, How They Fail, New York : Vintage, 1979, pp. 3-4.

4. Oberschall (Anthony), Social Movements: Ideologies, Interests, and Identities, New Brunswick (USA) / London (UK) : Transaction Publishers, 1993, p. 49.

5. Cf. London (Kurt), "Communism in Eastern Europe : Polycentrism, Splittism and After », in London (Kurt), ed., Eastern Europe in Transition, Baltimore: The John Hopkins University Press, 1966.

6. Oberschall (Anthony), «Protest Demonstrations and the End of Communist Regimes in $1989 »$, Research in Social Movements, Conflicts and Change, 17, 1994.

7. Tarifa (Fatos), « East European Puzzles : Old and New », Sociological Analysis, 1 (2), 1998.

8. Meyer (Alfred, G.), «Legitimacy of Power in East Central Europe », in Sinanian (S.), Deak (I.), Luddz (P.C.), eds., Eastern Europe in the 1970s, New York : Praeger Publishers, 1972.

9. Tarifa (Fatos), « The Quest for Legitimacy and the Withering Away of Utopia », Social Forces, 76 (2), 1997 
10. Szelényi (Iván), Szelényi (Balazs), «Why Socialism Failed: Toward a Theory of System Breakdown. Causes of Disintegration of East European State Socialism », Theory and Society, 23, 1994.

11. Habermas (Jürgen), Legitimation Crisis, Boston : Beacon Press, 1975, p. 75

12. Kateb (George), « On the "Legitimation Crisis" », Social Research, 46 (4), 1979, p. 696.

13. Osiatynski (Viktor), "Revolutions in Eastern Europe ", The University of Chicago Law Review, 58 (2), 1991.

14. Brown (James F.), Eastern Europe and Communist Rule, Durham and London : Duke University Press, 1988.

15. Osiatynski (Viktor), art. cit.; Banac (Ivo), "Political Change and National Diversity", Daedalus, 119 (1), 1990.

16. Chirot (Daniel), "What Happened in Eastern Europe in 1989?», in Chirot (Daniel), ed., The Crisis of Leninism and the Decline of the Left : The Revolutions of 1989, Seattle and London : University of Washington Press, 1991, pp. 8-9.

17. Tarifa (Fatos), « Albania's Road from Communism : Political and Social Change, 1990-1993 », Development and Change, 26 (1), 1995.

18. Russell (Bertrand), Power : A New Social Analysis, New York: W.W. Norton \& Company, Inc., 1969, p. 152.

19. Lovenduski (Joni), Woodall (Jean), Politics and Society in Eastern Europe, London : Macmillan Education Ltd., 1987; Gitelman (Zvi), «The Politics of Socialist Restoration in Hungary and Czechoslovakia », Comparative Politics, 13, 1981 ; Szelényi (Iván), Szelényi (Balazs), art.cit.

20. Collins (Randall), Weberian Sociological Theory, Cambridge : Cambridge University Press, 1986, p. 60 .

21. Chorley (Katherine), Armies and the Art of Revolution, Boston : Beacon Press, 1973.

22. Arendt (Hannah), On Revolutions, New York: Viking Press, 1963, p. 153.

23. Kolakowski (Leszek), "Mind and Body: Ideology and Economy in the Collapse of Communism », in Poznanski (K.Z.), ed., Constructing Capitalism: The Emergence of Civil Society and Liberal Economy in the Post-Communist World, Boulder : Westview Press, 1992.

24. Quoted in Poggi (Gianfranco), The State: Its Nature, Development, and Prospects, Stanford: Stanford University Press, 1990, p. 28.

25. Lipset (Seymour Martin), The First New Nation, New York : Norton, 1979 (expanded edition) ; Lipset (Seymour Martin), Political Man: The Social Basis of Politics, Baltimore: The John Hopkins University Press, 1981 (expanded edition) ; Lipset (Seymour Martin), «The Social Requisites of Democracy Revisited", American Sociological Review, 59 (1), 1994 ; Diamond (Larry), "Three Paradoxes of Democracy ", Journal of Democracy, 1 (3), 1990 ; Diamond (Larry), Linz (Juan J.), Lipset (Seymour Martin), eds., Politics in Developing Countries: Comparing Experiences with Democracy, Boulder : Lynne Rienner, 1990

26. McSweeney (Dean), Tempest (clive), «The Political Science of Democratic Transition in Eastern Europe », Political Studies, 41 (3), 1993.

27. Reykowski (Janusz), « Why Did the Collectivist State Fail ?», Theory and Society, 23, 1994.

28. Nee (Victor), Lian (Peng), «Sleeping with the Enemy: A Dynamic Model of Declining Political Commitment in State Socialism », Theory and Society, 23, 1994.

29. Rév (István), « The Postmortem Victory of Communism », Daedalus, 123 (3), 1994.

30. Nee (Victor), Lian (Peng), art.cit., p. 284.

31. Kolakowski (Leszek), art.cit., 1992.

32. Ibid.

33. Fukuyama (Francis), The End of History and the Last Man, New York: Avon Books, 1993, p. 15.

34. Chirot (Daniel), art.cit.; Szelényi (Iván), Szelényi (Balazs), art.cit.; Gaay Fortman (Bas de), « Is Socialism Possible? » Sociological Analysis, 1 (1), 1998.

35. Gaay Fortman (Bas de), art.cit., p. 219. 
36. Economicheskie Nauki, 1987, 4, p. 14.

37. A survey by The Economist (05/12/92) estimated that the former Soviet Union would use per unit of GDP 15 times as much steel, nine times as much rubber, and six times as much energy as the U.S. used. According to The Economist, if all the raw materials that the Soviet economy produced were sold abroad, this country would have earned twice as much as its actual GDP.

38. Galdbraith (John Keneth), Menshikov (S.), Capitalism, Communism, and Coexistence: From the Bitter Past to a Better Prospect, Boston : Houghton Mifflin Company, 1988, p. 45.

39. Kolakowski (Leszek), art.cit., p. 12.

40. Szelényi (Iván), Szelényi (Balazs), art.cit. p. 218.

41. Kadare (Ismail), Albanian Spring: The Anatomy of Tyranny, London : Saqi Books, 1995, p. 157.

\section{ABSTRACTS}

Employing a comparative historical approach, this article examines the differences that existed between the Visegrád countries, on one side, and the Balkan countries, on the other, with regard to the legitimacy of their communist rule. Among the later, the article focuses primarily on the cases of Albania and the former Yugoslavia as deviants from the more general pattern of the Soviet-block countries. The article argues why legitimation crisis of state socialism broke out mainly - and most dramatically - in East Central Europe and not in the Balkans.

Utilisant une approche historique comparative, l'auteur analyse les différences entre les pays de Visegrad et ceux des Balkans, en regard de la légitimité de leur direction communiste. En ce qui concerne les Balkans, l'auteur se penche plus particulièrement les cas de l'Albanie et de l'ancienne Yougoslavie, déviants par rapport au modèle soviétique applicable au bloc de l'Est. L'article explique pourquoi la crise de légitimité du communisme s'est principalement déroulé, et d'une manière dramatique, en Europe centrale et non dans les Balkans.

\section{AUTHOR}

\section{FATOS TARIFA}

F. Tarifa is Director of the New Sociological Research Center at Tirana, and Chief Editor of Sociological Analysis. He currently teaches sociology and international relations at the University of North Carolina at Chapel Hill. 